Article

\title{
Pyrolysis Conversion of Polymer Wastes to Noble Fuels in Conditions of the Slovak Republic
}

\author{
Michal Holubčík ${ }^{1, *(1)}$, Ivana Klačková ${ }^{2}\left(\mathbb{D}\right.$ and Peter Ďurčanský ${ }^{1}$ (1) \\ 1 Department of Power Engineering, Faculty of Mechanical Engineering, University of Žilina, Univerzitná 1, \\ 01026 Žilina, Slovakia; peter.durcansky@fstroj.uniza.sk \\ 2 Department of Automation and Production systems, Faculty of Mechanical Engineering, University of \\ Žilina, Univerzitná 1, 01026 Žilina, Slovakia; ivana.klackova@fstroj.uniza.sk \\ * Correspondence: michal.holubcik@fstroj.uniza.sk; Tel.: +421-415132855
}

Received: 13 August 2020; Accepted: 14 September 2020; Published: 16 September 2020

\begin{abstract}
This paper deals with the pyrolysis conversion of synthetic waste materials into noble fuels, i.e., heating oils, gasoline, diesel, and carbon. The following article presents the principle and use of pyrolysis conversion of waste tires and plastics. The core of the paper is the determination of energy properties of noble fuels obtained from pyrolysis conversion and the possibility of their real use in industry. The aim of this paper is a technical-economic evaluation of the use of waste pyrolysis in practice in the Slovak Republic. Unlike various methods of waste management, there are also more efficient methods, which primarily have a positive effect on the ecology of our Earth and at the same time can be effectively used for the production of alternative fuels. One of these methods is the pyrolysis conversion of synthetic waste materials into noble fuels. It is an ecological, waste-free, economical, and economical disposal of waste with a full recovery of its energy and material components with reduced emissions, and therefore this direction of using synthetic waste for the conversion of alternative fuels contributes to sustainable development. A significant advantage of this waste management is considered to be the fact that only waste tires or chlorine-free plastics are used as input materials without other necessary raw materials obtained by other economic activity. Tires and plastics are generated daily as waste in every household.
\end{abstract}

Keywords: polymer waste; pyrolysis; noble fuel; energetic properties

\section{Introduction}

In nature, no object ends as waste. For example, a tree uses nutrients contained in soil and sunlight to grow. The leaves fall in the fall and the tree returns these nutrients and energy back to the soil for other organisms to use. Such processes are called cycles because they simply take advantage of the constant exchange of energy needed for growth [1]. On the other hand, humanity, through its economic activity, continuously generates waste that adversely affects our planet. Naturally, this waste cannot be converted into usable energy on its own. New technologies and processes are emerging via intensive research, where the current worldwide energy production and consumption should be changed. The high dependence on fossil fuels and rising consumption can cause depletion of these resources with negative impact on the environment, e.g., global warming and pollution with harmful matters like Sulphur dioxide $\left(\mathrm{SO}_{2}\right)$, Nitrogen oxides $\left(\mathrm{NO}_{\mathrm{x}}\right)$, and Volatile organic compounds (VOCs). Another rising issue is a solid waste disposal [2,3].

Most families in Slovakia currently own one to two cars that take them comfortably to work, on trips, and the like. As the years of the car use pass, the number of kilometers driven also increases. The tires wear out and the rubber ages and hardens on them. Every car needs every 4-6 years a complete replacement of all four tires. Of course, their wear depends mainly on the number of 
kilometers driven and the way they drive. Then, the question is: What can be done with old tires? Thus, more than 30,000 tons are generated annually in Slovakia. Tires are not municipal waste, so they cannot be thrown into the container. In 1 January 2016, the Waste Act no. 79/2015 came into effect, which defines responsibilities for used tires at the end of their service life. Worn tires can now be handed over at any tire service, tire or car dealer and collection points designated by the municipality. These entities are obliged to take care of their disposal, recycling or material or energy recovery. Any such place marked as a "tire take-back point" is mandatory for all types of tires, regardless of the place of purchase, make, or size.

The situation is similar with plastic products used in households. Packaging materials are increasingly being used, resulting in more and more polymer waste. In accordance with Act 79/2015, the goal of waste management in the field of packaging waste management in the Slovak Republic is to achieve a recovery rate for individual packaging materials (waste streams) of at least $48 \%$ by weight of plastic packaging waste and recycling rate for individual packaging materials (streams waste) at least $45 \%$ by weight of plastic packaging waste.

There are effective methods of waste management which primarily have a positive effect on the ecology of our Earth and at the same time can be effectively used for the production of alternative fuels $[4,5]$. One of these methods is the pyrolysis conversion of synthetic waste materials into noble fuels. It is an ecological, waste-free, and economical disposal of waste with a full recovery of its energy and material component with reduced emissions, and therefore this direction of using synthetic waste for the conversion of alternative fuels contributes to sustainable development. The fact that only waste tires or chlorine-free plastics without other necessary raw materials obtained by other economic activity are used as input raw materials should be also considered as the significant advantage of this waste management.

Another technology available for recycling of plastics and their characteristics are: thermal cracking (conventional pyrolysis-plasma pyrolysis, microwave-assisted pyrolysis), catalytic cracking, hydrocracking, conventional gasification, plasma gasification, pyrolysis with in-line reforming [6]. An interesting technology is also catalytic fast pyrolysis of waste polymers. Pyrolysis, an efficient and eco-friendly process, is a feasible alternative for the production of fuels, chemicals, and hydrogen from biomasses and waste polymers. Pyrolysis methods can be divided into two major categories, i.e., slow and fast pyrolysis. Slow pyrolysis involves a slow heating rates of $0.1-1{ }^{\circ} \mathrm{C} / \mathrm{s}$, a residence time varying from minutes to hours and a temperature range of $400-600^{\circ} \mathrm{C}$. In contrast, fast pyrolysis rapidly heats samples to $400-600{ }^{\circ} \mathrm{C}$ with a heating rate of $10-1000{ }^{\circ} \mathrm{C} / \mathrm{s}$ in a non-oxidizing environment during a short residence time $(<2 \mathrm{~s})$ and produced pyrolysis vapors are rapidly quenched [7].

Polymers, as materials that are used daily, contribute fundamentally in our daily waste production. Daily use in vast applications in various sectors resulted into enormously increased global production and disposal over the years [8]. Waste polymeric materials can be described as mixtures of different polymer molecules, for example high density polyethylene (HDPE), low density polyethylene (LDPE), polyethylene terephthalate (PET), polypropylene (PP), polystyrene (PS), polyamide(PA), polyvinyl-chloride(PVC), polyacrylate (PAC), etc., $[9,10]$. One possible use of these materials, when they are disposed, is the conversion via slow pyrolysis, where the final product includes syngas, pyrolysis oil, and biochar [11]. Syngas or synthesis gas is a mixture of carbon monoxide, hydrogen, carbon dioxide and other gas compounds with variable composition. Higher operating temperature, long time residence heating rates with slow quenching of the waste enabled the production of syngas with raised percentages of $\mathrm{H}_{2}, \mathrm{CO}, \mathrm{CO}_{2}$, and light hydrocarbons in the gas phase [12]. Pyrolysis oil comprises hydrocarbons, aromatic hydrocarbons, benzene derivatives and oxygenates [13]. Raw char can be used only after pretreatment. Carbon enrichment is required and then, as black carbon, this material can be used for the tires production or as an improved carbon material it can be used as an absorber or catalyst [14].

This article was written on the basis of a newly emerging pyrolysis plant in the village of North Slovakia. All the obtained information, values, and samples of input and output raw materials from 
the plant helped to set up the overall operation process more efficiently through measurements, analyzes and the final technical and economic evaluation of the pyrolysis plant.

\section{Used Materials}

From the synthetic waste materials suitable for pyrolysis, tires and plastics were chosen, given that they are generated daily as waste in every household and they are the most extended polymer materials in Slovakia.

\subsection{Waste Tires}

Tires are complex products, consisting of different materials and different properties [15]. Tires can be described as complex engineered products, made of different components with a wide range of desired properties. They consist from many dissimilar parts and form a very complex structure, which should be able to operate under a wide range of conditions [16]. Their production is demanding in terms of precision and technology. The role of the tires is to reliably transmit the driving and steering forces to the road and also to absorb the shocks acting on the vehicle when driving on uneven surfaces. It also significantly affects the safety and comfort of driving the vehicle. The tires work on the principle of a pressure vessel, where the tire walls are formed by a flexible membrane. Based on the construction, we divide them into tires with a tube and without a tube (so-called tubeless tires). The necessary raw materials needed for the production of tires are natural or synthetic rubbers, so-called elastomers. It is well known that the tire industry is the biggest market and consumer of natural and synthetic rubbers $[17,18]$. In addition, rubber compounds, cords made of natural and chemical fibers, as well as cords made of steel fibers are added to the mixture. In addition to these main raw materials, a steel heel cable is also included.

Complete and accurate assembly is very demanding, as the mixture of tires is always different. Specifically, we can say what the manufacturer, the different composition of the tire, so the final composition of all rubber compounds is the secret of individual manufacturers. As a percentage, the composition of the tires can be expressed as follows:

- Rubber: $38 \%$

- Fillers (carbon black, silica, carbon): $30 \%$

- Reinforcement material (steel, rayon, nylon): $16 \%$

- Emollients (oils and resins): $10 \%$

- Vulcanizing agents (sulfur, zinc oxide, various chemicals): $4 \%$

- Antioxidants against material fatigue: $1 \%$

- Mixed material: $1 \%$

It is assumed that more than hundred different chemical agents can be added to the tire mixture for specific trademark, for needed specific use $[19,20]$. Due to the tire heterogeneity, an alternative treatment process for waste tires can only be used where the use of pyrolysis technology gives a feasible alternative [21].

Radial tires of various sizes were used as input material, most of which were truck and tractor tires. Waste tires were collected from local tire services and black dumps in the area around northern Slovakia. The tires were crushed to a fraction size of up to $100 \mathrm{~mm}$.

\subsection{Waste Plastics}

Plastics penetrate the daily lives of people in all industrialized countries during the 20th century. Polymers are currently the most important segment of production and consumption by volume among all technical materials. They are easy to process and have a low density and a favorable ratio between performance and price. However, further development of polymeric materials is still ongoing. At present, there are a number of plastics, different ways of their production and processing, which result from the expanding field of their use [22]. 
Plastics constitute the mixture of many substances, including macromolecular substances (polymers) and different additives, such as pigments, plasticizers, fillers, and flame retardants, because they are compounds built from a large number of atoms while their connection takes place mainly by chemical bonds [23]. They are formed by macromolecular chains with repeating basic structural units.

When heat and pressure are applied to the thermoplastic binder, the polymer chains begin to slide around each other, giving the material plasticity. Resource recovery from plastics can be divided into material recycling and energy recovery. The chosen process depends on the plastics type, the relative difficulty in total or partial segregation from other waste materials, and the ecological and cost aspects of the process [24].

The properties of plastics depend on their structure and the length of the chains composed of macromolecules. Plastics are strong, rigid at normal temperatures, and are usually easy to shape, machinable, and have good insulating properties. Their disadvantage is their low resistance to higher temperatures. They are not subject to corrosion, which is an advantage in terms of the stability of the products made from them, but a disadvantage in terms of the environment. Plastics as well as any other material are subject to change. Due to various factors, they lose their original properties, age, and degrade.

Plastic waste mix with of polystyrene waste, polyethylene waste, laminates, packaging waste and solid plastic municipal waste was used during experiments in pyrolysis reactor. Waste plastics were collected from local plastics distributors in the area around northern Slovakia. The plastic wastes were crushed to a fraction size of up to $100 \mathrm{~mm}$.

\section{Used Pyrolysis Process}

At present, pyrolysis is considered an attractive technology. It is also related to the fact that it takes place at relatively low temperatures, which leads to a lower emission of potential pollutants compared to the complete incineration of waste materials.

From the technological point of view, we can divide the pyrolysis processes according to the achieved temperature into:

- $\quad$ Low temperature (below $500^{\circ} \mathrm{C}$ )

- Medium temperature $\left(500-800^{\circ} \mathrm{C}\right)$

- High temperature (above $800{ }^{\circ} \mathrm{C}$ )

Within these conditions, we can also assume, that pyrolysis products are varying not only according to type of pyrolysis material. It seems valuable to obtain a database indicating the pyrolysis product yields and quality for chosen plastics class. However, pyrolysis conditions, such as time and material composition, also affect process itself. Among many operational conditions, pyrolysis temperature seems to be one of the most important operating parameters affecting the final product composition. Higher operating temperatures enable bond breaking and facilitate the production of smaller molecules [25]. Gaseous products in reactor $\left(C_{2}-C_{4}\right)$ increase and liquid products $\left(C_{5}-C_{9}\right)$ decrease with increase in working temperature [26]. Catalysts effect on the yields and structure of products are less significant with increasing temperature [24,27]. The main purpose of this present study is the comparison of the liquid product yields from PE, PET, PP, and PS under the same pyrolysis conditions and the investigation of the pyrolysis temperature effect at this liquid product yields and heat values. Also, the effect of plastic waste pre-washing process is investigated where the prewashing removes impurities from the waste samples and the waste composition for pyrolysis is changing [22].

At present, most process pyrolysis is based on the thermal decomposition of waste in a rotary kiln heated by the combustion of pyrolysis gases in a thermos reactor. Pyrolysis units are suitable for incineration of waste that does not have too high a content of pollutants and does not tend to sinter.

The term pyrolysis means a thermochemical process in which materials without access to atmospheric oxygen, i.e., anaerobically, are rapidly heated to a temperature of $200{ }^{\circ} \mathrm{C}$ to $1000{ }^{\circ} \mathrm{C}$ [23]. 
It is a process of cleavage of macromolecular compounds into still low molecular weight products and a solid residue. The plastics thermal degradation has a rising tendency as a material recycling method with conversion to gas, liquid (oil) and solid products, where each by-product can be used as energy source or chemical feedstock. Pyrolysis products composition and yield are related directly to the reaction conditions (temperature, heating rate, pressure, presence of catalyst etc.), as well as pyrolysis material structure $[24,28]$. The end results of the pyrolysis process are: pyrolysis gas (containing mainly methane, hydrogen, carbon dioxide), solid residue (carbon, steel cords), and liquid product (gasoline, diesel, pyrolysis oil).

There are several reactor types which can be used in the waste tires pyrolysis process, for example reactor with fixed bed (batch), screw kiln, rotary kiln, fluidized, and vacuum-bed [29,30].

During present experiments was used fixed bed reactor. The waste material was put on to the bed in batches before starting of the pyrolysis process like similar to the work [30].

The technology represents one of the new methods of waste-free recovery of tires and plastics. This is recovery by pyrolysis at temperatures $200-240{ }^{\circ} \mathrm{C}$. First, the dispenser is filled with synthetic waste raw materials (in present study it was tires, various plastics and a mix of tires and plastics) and the raw materials are transported to the reactor using a dosing device. The pyrolysis itself takes place in a reactor, which is initially heated by wood. The process takes place without air access, so there is no oxidation-combustion. Thermal decomposition produces pyrolysis carbon and a steam-gas mixture in the reactor, which is sucked out and cooled from the reaction space. The resulting gas is returned to combustion. After cooling, liquid hydrocarbons, which are similar in composition to oil, condense and remain non-liquid in gaseous form as a pyrolysis gas, consisting mainly of methane and hydrogen, which is removed by means of an excess gas line. The reactor is hermetically sealed, and none of the pyrolysis products enter the environment. The chimney traps the wood flue gases, which pass through the water labyrinth, further into the shower column and again through the water labyrinth, thus cleaning the flue gases. When the pyrolysis process is complete, after cooling, the carbon is vented from the reactor through the bottom orifice and the unburned wires are removed through the inlet.

\section{Methods of Experiments}

During experiments, various properties of waste tires, plastic waste, and products of pyrolysis process were obtained.

\subsection{Methodology for Determination of Hydrogen, Nitrogen, Carbon and Sulfur Content of Input and Output Materials}

To determine the content of hydrogen, nitrogen, carbon, used was the LECO CHN 628 instrument. The average value from the measured values was always determined from three measurements for each sample. The CHN 628 uses the principle of the Dumas combustion method [31], which is very robust, accurate, fast, and not demanding on chemicals.

The analyzed sample is weighed into different types of capsules or the foil is inserted into the sample feeder. From there, the sample falls into the cleaning intermediate chamber, where any adverse effects of the surrounding atmosphere are removed. The sample then travels to the kiln, where it is burned. The resulting gases are then entrained in a stream of oxygen into the secondary combustion tube for better oxidation and removal of unwanted particles. The gas mixture is accumulated in the so-called a ballast vessel where the gases are stabilized and homogenized. Only an aliquot containing a representative sample is transferred to the so-called an aliquot separator into the detection system. Each element has a separate IR detection cell for the detection of C, H and $S$ and a TC cell for the detection of $\mathrm{N}$, which speeds up the analysis time. An optional sulfur detection plug-in can be connected to all $\mathrm{N}, \mathrm{C} / \mathrm{N}$, and $\mathrm{C} / \mathrm{H} / \mathrm{N}$ combinations and is used to analyze the sulfur of a wide range of organic materials such as coal, coke, heating oils, as well as inorganic materials such as soil, limestone, etc. [32]. 
The CHN 628 has flexible and easy-to-use software running in a Windows ${ }^{\circledR}$ environment. Practically unlimited capacity for data storage and measured results, or export to LINS systems. The software contains a full manual and operating instructions, which provide the operator with the necessary information without leaving the device. The software also meets the requirements of Food and Drug Administration (FDA) 21 CFR Part 11 regulations for a closed analytical system.

\subsection{Methodology for Determination of Calorific Value of Input and Output Materials}

The heat of combustion was measured using a calorimeter. Combustion heat is the amount of heat that is released by the perfect combustion of a unit amount of fuel.

Calorific value is the heat of combustion reduced by the heat of vaporization of the water released from the fuel during the combustion time. The value of combustion heat is always greater than or at least equal to the value of calorific value.

A calorimeter is an instrument for measuring the specific heat of substances or the heat quantity converted in chemical and physical processes. A mixing calorimeter is used as the simplest type to measure heat capacity. The calorimeter works on the principle that a certain amount of heat is supplied (removed) to a test substance of a certain weight, and the temperature changes that occur are measured.

The measurement of combustion heat is based on the law of conservation of energy (1). The heat transferred by the test substance must be equal to the heat received by the water received by the calorimeter.

$$
\mathrm{Q}_{\mathrm{k}}=\mathrm{Q}_{\mathrm{v}}+\mathrm{Q}_{\mathrm{K}}
$$

where $Q_{k}$ denotes the heat transferred by the test substance, $Q_{v}$ the heat received by water, and $Q_{K}$ the heat received by the calorimeter

The calorific value is calculated on the basis of the measured heat of combustion on the calorimeter and the measured humidity on the drying balance.

The calorific value is given by:

$$
\mathrm{Q}_{\mathrm{i}}=\mathrm{Q}_{\mathrm{s}}-2.453 .\left(\mathrm{w}+9 \mathrm{H}_{2}\right)
$$

where $Q_{i}$ is the calorific value $(\mathrm{MJ} / \mathrm{kg}), \mathrm{Q}_{\mathrm{s}}$ the heat of combustion $(\mathrm{MJ} / \mathrm{kg})$, w the humidity $(\mathrm{kg} / \mathrm{kg})$, and $\mathrm{H}_{2}$ the hydrogen content $(\mathrm{kg} / \mathrm{kg})$.

\subsection{Methodology for Determining the Content of Ash, Volatile Substances and Solid Carbon of Materials}

LECO TGA 701 was used as instrument (thermogravimetric analyzer for organic, inorganic, and synthetic samples) to determine the content of ash, volatile substances, and solid carbon of the input raw materials [33]. Volatile content was determined in nitrogen atmosphere with gas flow $10 \mathrm{~L} / \mathrm{min}$ without oxygen access at temperature $900{ }^{\circ} \mathrm{C}$ for $7 \mathrm{~min}$. Ash content and also solid carbon content was determined in oxygen atmosphere with gas flow $10 \mathrm{l} / \mathrm{min}$ at temperature $815^{\circ} \mathrm{C}$ until a constant weight was reached which took approximately $180 \mathrm{~min}$.

\section{Results and Discussion}

Pyrolysis of polymer wastes takes place in a pyrolysis reactor. The following process conditions were in the reactor:

- Absence of oxygen.

- Temperature range between 200 and $240{ }^{\circ} \mathrm{C}$.

- Mixing to speed up heat exchange.

In the pyrolysis process, the polymer waste was not incinerated, but had been divided into finished end products-pyrolysis oil and pyrolysis gas. The machines required for pyrolysis of waste plastics were the same as for pyrolysis of tires, but their maintenance was more difficult both for 
operation and for the cleaning of the machine itself. Compared to a tire, plastic waste offered even more disadvantages, such as:

- large differences in the specification of raw materials,

- content of unpredictable amounts of moisture and metal or non-plastic parts,

- in the reactor, plastic tends to stick to coke, which leads to a reduction in heat exchange, and

- a faster rate of pyrolysis reaction requires careful reactor design.

\subsection{The Results of the Input Material Properties}

The following chapter presents an analysis of input waste materials and their approximate mass balance. Various types of tires (tires from cars and trucks) were used as input raw materials, from plastic waste it was insulation-polystyrene, which is used in the insulation of buildings. The resulting contents of carbon, nitrogen, hydrogen and sulfur, volatiles, fixed carbon, and ash were determined. From the measured and averaged values of combustion heat the calorific value was calculated from the input raw materials. These average values of waste materials parameters are in the Table 1 . Waste tires had different properties in comparison with waste plastics mix. Major differences were noted in volatile content-plastics had higher volatile content in comparison with waste tires but it was markedly lower in comparison with traditional plastics like Polyethylene Terephthalate (PET) with $86.75 \div 91.75 \%$ volatile content in the articles [34-36], Polyethylene (PE) with $98.87 \%$ volatile content [37] and polystyrene (PS) with $99.5 \div 99.78 \%$ volatile content in the works $[36,38,39]$. This is related to the ash content in these waste plastics $(4.59 \%)$ in comparison with traditional plastics-PET, PE and PS have fixed carbon about $0 \div 0.99 \%[34,35,37,38]$. Our experiments confirmed that waste tires contain more than $80 \%$ of Carbon $(\mathrm{C}), 7.78 \%$ of Hydrogen $(\mathrm{H}), 1.29 \%$ of Nitrogen and $1.11 \%$ of Sulphur similar to at work [40]. Mix of waste plastics contain more than $78 \%$ of Carbon, $9.32 \%$ of Hydrogen, $4.93 \%$ of Nitrogen and $0.13 \%$ of Sulphur what is similar to results of other works [34,41]. Polymer materials have significantly higher energy content than standard fuels like wood and coal. Calorific value of waste tires was $34.16 \mathrm{MJ} / \mathrm{kg}$ and calorific value of waste plastics mix was approximately $29 \mathrm{MJ} / \mathrm{kg}$ what is similar to results of other works [2,24,42-44].

Table 1. Input waste materials parameters.

\begin{tabular}{cccc}
\hline Parameter & Unit & Waste Tires & Waste Plastics \\
\hline Volatile content & wt. $\%_{\text {dry }}$ & 72.25 & 88.12 \\
Fixed carbon content & wt. $\%_{\text {dry }}$ & 19.92 & 7.29 \\
Ash & wt. $\%_{\text {dry }}$ & 6.87 & 4.59 \\
C content & wt. $\%_{\text {dry }}$ & 80.69 & 78.65 \\
H content & wt. $\%_{\text {dry }}$ & 7.78 & 9.32 \\
N content & wt. $\%_{\text {dry }}$ & 1.29 & 4.93 \\
S content & wt. $\%_{\text {dry }}$ & 1.11 & 0.13 \\
Combustion heat & MJ $/ \mathrm{kg}$ & 36.18 & 31.01 \\
Calorific value & $\mathrm{MJ} / \mathrm{kg}$ & 34.16 & 28.95 \\
\hline
\end{tabular}

\subsection{The Results of the Final Products Properties}

During pyrolysis of the waste tires was created approximately wt. $45 \%$ of liquid products (gasoline, diesel, pyrolysis oil), wt. $30 \%$ of pyrolysis carbon, wt. 10\% pyrolysis gas (containing mainly methane, hydrogen, carbon dioxide) and wt. $15 \%$ of solid residue (steel cords). These results are similar to other works [2,45]. During pyrolysis of the waste plastics were created approximately wt. $90 \%$ of liquid products (gasoline, diesel, pyrolysis oil), and wt. 10\% pyrolysis gas (containing mainly methane, hydrogen, carbon dioxide). These results are similar to other works [20,44]. Approximately $450 \mathrm{~kg}$ of pyrolysis carbon, a total of approximately $400 \mathrm{~L}$ of liquid pyrolysis products and approximately $100 \mathrm{~kg}$ of steel cords were obtained from 1 ton of waste tires after the process. Approximately a total of approximately $900 \mathrm{~L}$ of liquid pyrolysis products were obtained from 1 ton of waste plastics after 
the process. The parameters of the final products from pyrolysis of waste tires are in Table 2. Liquid pyrolysis products were divided into pyrolysis oil, diesel and gasoline during process and they are similar to properties of pyrolysis oils in other works [45-47]. Produced pyrolysis oil is close to the properties of kerosene and also has a calorific value almost the same as kerosene. It could be widely used as an industrial fuel that can replace heating oil or industrial diesel. Heating with oil fuel boilers is currently one of the ecological and energy-saving methods of heating. However, it is not very widespread in Slovakia. It is different abroad, especially in western and southern countries, where every third household uses oil heating. Heating oil boilers are similar to gas boilers and they can also be combined with other heat sources. Produced diesel from pyrolysis of waste tires had very similar parameters like standard diesel from petrol station and it was experimentally smoothly used in diesel engine in tractor. Similarly, gasoline from pyrolysis of waste tires had very similar parameters like standard gasoline from petrol station. Produced carbon from pyrolysis had very similar properties like black coal but it was in the form of powder. It could be used in fluid bed boilers or after compaction into pellets or briquettes. Approximately $15 \%$ of final products were steel cords that can be sold for scrap iron.

Table 2. Final products of waste tires pyrolysis parameters.

\begin{tabular}{cccccc}
\hline Parameter & Unit & Pyrolysis Oil & Diesel & Gasoline & $\begin{array}{c}\text { Pyrolysis } \\
\text { Carbon }\end{array}$ \\
\hline Character & - & $\begin{array}{c}\text { light brown to } \\
\text { dark brown } \\
\text { viscous liquid }\end{array}$ & $\begin{array}{c}\text { light brown } \\
\text { liquid }\end{array}$ & $\begin{array}{c}\text { dark brown } \\
\text { liquid }\end{array}$ & black powder \\
\hline C content & wt. \% ${ }_{\text {dry }}$ & 83.27 & 60.37 & 63.55 & 64.43 \\
\hline H content & wt. \% ${ }_{\text {dry }}$ & 10.97 & 8.07 & 8.92 & 4.08 \\
\hline N content & wt. $\%$ dry & 4.57 & 2.28 & 3.56 & 2.86 \\
\hline S content & wt. \% ${ }_{\text {dry }}$ & 0.75 & 0.62 & 1.91 & 1.75 \\
\hline Ash & wt. \% dry & $<0.005$ & $<0.005$ & $<0.005$ & 29.84 \\
\hline Calorific value & MJ/kg & 40.85 & 41.61 & 41.99 & 23.73 \\
\hline
\end{tabular}

Certification of pyrolysis products was not realized due to the low production and use of manufactured products by the manufacturer. Various methods of purifying should be used for obtained gases like applying of membranes and amino techniques. Solid particles, tars and water must be removed from the gas after pyrolysis for further use. Membrane gas separation is based on the selective permeability of organic vapors as they pass through the membrane. Pyrolysis gas from experiments was not modified and it was burned for pyrolysis reactor heating.

The solid pyrolysis product can be physically and chemically modified. Types of modifications can be divided into groups into: mechanical (grinding), chemical-gas or vapor activation, application of acid catalysts (e.g., sulfuric or citric acid), basic catalyst (e.g., potassium hydroxide) or by adding metal salts [48], oxidation and reduction, physical (sonication), and combinations of these species [49]. Pyrolysis carbon from experiments was not modified.

The parameters of the final products from pyrolysis of waste plastics are in Table 3. During pyrolysis process of plastic waste were created only liquid products-pyrolysis oil, diesel, and gasoline. Pyrolysis oil produced from plastics had no similar properties like pyrolysis oil from waste tires because it had lower Carbon, Hydrogen, Nitrogen, and Sulphur content which led to a lower calorific value. This value of calorific value is significantly lower than produced pyrolysis oils in other works $[22,50,51]$. Produced diesel from pyrolysis of waste plastics had very similar parameters like standard diesel from petrol station and it was also experimentally smoothly used in diesel engine in tractor. Similarly, gasoline from pyrolysis of waste tires had very similar parameters like standard gasoline from a petrol 
station. The calorific value of standard gasoline is $42 \div 47.3 \mathrm{MJ} / \mathrm{kg}$ [50,52-54]. During the pyrolysis of waste plastics, there was minimal production of solid carbon.

Table 3. Final products of waste plastics pyrolysis parameters.

\begin{tabular}{ccccc}
\hline Parameter & Unit & Pyrolysis Oil & Diesel & Gasoline \\
\hline Character & - & $\begin{array}{c}\text { light brown to dark } \\
\text { brown viscous liquid }\end{array}$ & light brown liquid & dark brown liquid \\
C content & wt. \%dry & 60.84 & 62.81 & 61.89 \\
H content & wt. \%dry & 7.97 & 8.34 & 8.79 \\
N content & wt. \%dry & 2.01 & 2.45 & 3.61 \\
S content & wt. \%dry & 0.35 & 0.46 & 0.64 \\
Ash & wt. \%dry & $<0.005$ & $<0.005$ & $<0.005$ \\
Calorific value & MJ/kg & 26.29 & 42.56 & 42.34 \\
\hline
\end{tabular}

\section{Conclusions}

Today's world generates millions of tons of plastic waste and tires every month that are not environmentally acceptable waste. If we look only at the market of the Slovak Republic, the potential of these waste tires and waste plastics is currently estimated at approximately 100,000 tons. Given the expected development of motoring in particular, but also transport in general and the development of car production, and with the increasing use of packaging and plastic materials, even larger amounts of waste suitable for pyrolysis can be considered in the future. Pyrolysis of plastics and tires can turn this waste into billions of euros worth of energy. Compared to full combustion, lower emissions of potential pollutants have been reported during pyrolysis. In the pyrolysis process, treating waste tires and chlorine-free plastics, the amount of liquid product reaches $45 \%-60 \%$ and this leads to a further reduction in the total volume of exhales. It follows that pyrolysis processes produce about a tenth of the volume in terms of exhaust fumes compared to complete combustion. This technology not only solves the serious environmental problem of disposing used tires and plastics, which many technologically advanced countries are trying to solve, but the process itself is a source of products that can be used in other industries. These are carbon, pyrolysis oil, pyrolysis gas and steel wire-cords.

Pyrolysis oil can be used in its crude state as an energy carrier, with other chemical and physical processes, e.g., hydrogenation, fractional distillation or cracking, it is possible to obtain individual components from this oil in pure or enriched state and use them in other chemical processes, syntheses, or simple burning processes.

The residual gas is partially recycled to the pyrolysis process itself, thereby consuming the hydrogen and $\mathrm{CO}$ produced. In such a process, the total volume of gases at the outlet will contain negligible concentrations of $\mathrm{CO}$ and will not contain thermal oxides of nitrogen. The rest of the energy from the combustion of the gas, which is not used to heat the inserted waste, is further used. Furthermore, the pyrolysis gas can be used directly as a chemical raw material or as a heating gas in cogeneration units for the production of electrical energy for heating the reactor and at the same time for the production of heat.

Pyrolysis carbon can further be reused in tires, as an additive to plant pellets, or as an additive to building materials, whereby the thermal insulation properties of these materials can be improved.

Polymer waste pyrolysis is an upcoming industry that will drive tomorrow's growth and protect the environment by cleaning landfills from waste tires as well as chlorine-free plastics.

Author Contributions: Conceptualization, M.H. and I.K.; Data curation, M.H.; Formal analysis, M.H. and I.K.; Funding acquisition, M.H.; Investigation, M.H.; Methodology, M.H.; Project administration, M.H.; Resources, M.H.; Supervision, M.H.; Validation, P.Ď.; Writing—original draft, M.H. and I.K.; Writing—review \& editing, P.Ď. All authors have read and agreed to the published version of the manuscript.

Funding: This research was funded by Agentúra na Podporu Výskumu a Vývoja: APVV-17-0311 and APVV 15-790 and, Vedecká Grantová Agentúra MŠVVaŠ SR a SAV: VEGA 1/0233/19. 
Acknowledgments: This work has been supported by the APVV-17-0311 "Research and development of zero waste technology for the decomposition and selection of undesirable components from process gas generated by the gasifier", VEGA 1/0233/19 "Construction modification of the burner for combustion of solid fuels in small heat sources" and APVV-15-0790 "Optimization of biomass combustion with low ash melting temperature".

Conflicts of Interest: The authors declare no conflict of interest.

\section{References}

1. Kuric, I. New methods and trends in product development and planning. In Proceedings of the 1st International Conference on Quality and Innovation in Engineering and Management (QIEM), Cluj Napoca, Romania, 17-19 March 2011; pp. 453-456.

2. Martinez, J.D.; Puy, N.; Murillo, R.; Garcia, T.; Navarro, M.V.; Mastral, A.M. Waste tyre pyrolysis-A review. Renew. Sustain. Energy Rev. 2013, 23, 179-213. [CrossRef]

3. Nosek, R.; Tun Maw, M.; Juchelkova, D. Energy Utilization of Spent Coffee Grounds in the Form of Pellets. Energies 2020, 13, 1235. [CrossRef]

4. Niemczuk, B.; Nieoczym, A.; Caban, J.; Marczuk, A. Analysis of chemical and energy properties of energy willow in the industrial burning. Przem. Chem. 2018, 97, 44-48.

5. Kuric, I.; Cisar, M.; Tlach, V. Technical Diagnostics at the Department of Automation and Production Systems. Book Ser. Adv. Intell. Syst. Comput. 2019, 835, 474-484.

6. Solis, M.; Silveira, S. Technologies for chemical recycling of household plastics-A technical review and TRL assessment. Waste Manag. 2020, 105, 128-138. [CrossRef]

7. Laibao, Z.; Zhenghong, B.; Shunxiang, X.; Qiang, L.; Walters, K.B. Catalytic Pyrolysis of Biomass and Polymer Wastes. Catalysts 2018, 8, 659.

8. Dwivedi, P.; Mishra, P.K.; Mondal, M.K.; Srivastava, N. Non-biodegradable polymeric waste pyrolysis for energy recovery. Heliyon 2019, 5, e02198. [CrossRef]

9. Shastri, V.P. Non-degradable biocompatible polymers in medicine: Past, present and future. Curr. Pharmaceut. Biotechnol. 2003, 4, 331-337. [CrossRef]

10. Ojeda, T. Polymers and the Environment; Polymer Science; IntechOpen: London, UK, 2013; Chapter 1; pp. 1-34.

11. Lu, J.S.; Chang, Y.; Poon, C.S.; Lee, D.J. Slow pyrolysis of municipal solid waste (MSW): A review. Bioresour. Technol. 2020, 312, 123615. [CrossRef]

12. González, J.F.; Encinar, J.M.; Canito, J.L.; Rodríguez, J.J. Pyrolysis of automobile tyre waste. Influence of operating variables and kinetics study. J. Anal. Appl. Pyrolysis 2001, 58-59, 667-683. [CrossRef]

13. Quesada, L.; Calero, M.; Martín-Lara, M.A.; Pérez, A.; Blázquez, G. Characterization of fuel produced by pyrolysis of plastic film obtained of municipal solid waste. Energy 2019, 186, 115874. [CrossRef]

14. Lewandowski, W.M.; Januszewicz, K.; Kosakowski, W. Efficiency and proportions of waste tyre pyrolysis products depending on the reactor type-A review. J. Anal. Appl. Pyrolysis 2019, 140, 25-53. [CrossRef]

15. Leung, D.Y.C.; Wang, C.L. Kinetic study of scrap tyre pyrolysis and combustion. J. Anal. Appl. Pyrolysis 1998, 45, 153-169. [CrossRef]

16. Ramarad, S.; Khalid, M.; Ratnam, C.T.; Luqman Chuah, A.; Rashmi, W. Waste tire rubber in polymer blends: A review on the evolution, properties and future. Prog. Mater. Sci. 2015, 72, 100-140. [CrossRef]

17. Fukumori, K.; Matsushita, M.; Okamoto, H.; Sato, N.; Suzuki, Y.; Takeuchi, K. Recycling technology of tire rubber. JSAE Rev. 2002, 23, 259-264. [CrossRef]

18. Shulman, V.L. Tyre recycling. In Waste; Academic Press: Boston, MA, USA, 2011; Chapter 21; pp. 297-320.

19. Mastral, A.M.; Murillo, R.; Callén, M.S.; García, T. Application of coal conversion technology to tire processing. Fuel Process. Technol. 1999, 60, 231-242. [CrossRef]

20. Mastral, A.M.; Murillo, R.; Callén, M.S.; García, T.; Snape, C.E. Influence of process variables on oils from tire pyrolysis and hydropyrolysis in a swept fixed bed reactor. Energy Fuel 2000, 14, 739-744. [CrossRef]

21. Sienkiewicz, M.; Kucinska-Lipka, J.; Janik, H.; Balas, A. Progress in used tyres management in the European Union: A review. Waste Manag. 2012, 32, 1742-1751. [CrossRef]

22. Sogancioglu, M.; Ahmetli, G.; Yel, E. A Comparative Study on Waste Plastics Pyrolysis Liquid Products Quantity and Energy Recovery Potential. Energy Procedia 2017, 118, 221-226. [CrossRef]

23. Mui, E.L.K.; Ko, D.C.K.; McKay, G. Production of active carbons from waste tyres-A review. Carbon 2004, 42, 2789-2805. [CrossRef] 
24. Panda, A.K.; Singh, R.K.; Mishra, D.K. Thermolysis of waste plastics to liquid fuel A suitable method for plastic waste management and manufacture of value added products-A world prospective. Renew. Sustain. Energy Rev. 2010, 14, 233-248. [CrossRef]

25. Miandad, R.; Barakat, M.A.; Aburiazaiza, A.S.; Rehan, M.; Ismail, I.M.I.; Nizami, A.S. Effect of plastic waste types on pyrolysis liquid oil. Int. Biodeterior. Biodegrad. 2016, 119, 239-252. [CrossRef]

26. Demirbas, A. Pyrolysis of municipal plastic waste for recovery of gasoline range hydrocarbons. J. Anal. Appl. Pyrolysis 2004, 72, 97-102. [CrossRef]

27. Miskolczi, N.; Bartha, L.; Deak, G.; Jover, B.; Kallo, D. Thermal and thermo-catalytic degradation of high-density polyethylene waste. J. Anal. Appl. Pyrolysis 2004, 72, 235-242. [CrossRef]

28. Kaminsky, W.; Zorriqueta, I.J.N. Catalytical and thermal pyrolysis of polyolefins. J. Anal. Appl. Pyrolysis 2007, 79, 368-374. [CrossRef]

29. Aydın, H.; İlkılıç, C. Optimization of fuel production from waste vehicle tires by pyrolysis and resembling to diesel fuel by various desulfurization methods. Fuel 2012, 102, 605-612. [CrossRef]

30. Arya, S.; Sharma, A.; Rawat, M.; Agrawal, A. Tyre pyrolysis oil as an alternative fuel: A review. Mater. Today Proc. 2020, 28, 2481-2484. [CrossRef]

31. Juras, P.; Durica, P.; Jandacka, J. Parametric Study: Impact of Selected Factors on the Energy Demand of a Family House. IOP Conf. Ser. Earth Environ. Sci. 2019, 290, 012096. [CrossRef]

32. Kolková, Z.; Hrabovský, P.; Matušov, J.; Nosek, R. Analysis of thermodynamic parameters and their influence on the thermal comfort in the working environment. MATEC Web Conf. 2018, 168, 04002. [CrossRef]

33. Micieta, J.; Hajek, J.; Jandacka, J. Simple model of pellet combustion in retort burner. Commun. Sci. Lett. Univ. Zilina 2015, 17, 34-39.

34. Heikkinen, J.M.; Hordijk, J.C.; De Jong, W.; Spliethoff, H. Thermogravimetry as a tool to classify waste components to be used for energy generation. J. Anal. Appl. Pyrolysis 2004, 71, 883-900. [CrossRef]

35. Zannikos, F.; Kalligeros, S.; Anastopoulos, G.; Lois, E. Converting biomass and waste plastic to solid fuel briquettes. J. Renew. Energy 2013, 9, 360368. [CrossRef]

36. Shafferina, D.A.S.; Faisal, A.; Wan, M.A.W.D.; Mohamed, K.A. Energy recovery from pyrolysis of plastic waste: Study on non-recycled plastics (NRP) data as the real measure of plastic waste. Energy Convers. Manag. 2017, 148, 925-934.

37. Jung, S.-H.; Cho, M.-H.; Kang, B.-S.; Kim, J.-S. Pyrolysis of a fraction of waste polypropylene and polyethylene for the recovery of BTX aromatics using a fluidized bed reactor. Fuel Process. Technol. 2010, 91, 277-284. [CrossRef]

38. Park, S.S.; Seo, D.K.; Lee, S.H.; Yu, T.-U.; Hwang, J. Study on pyrolysis characteristics of refuse plastic fuel using lab-scale tube furnace and thermogrivimetric analysis reactor. J. Anal. Appl. Pyrolysis 2012, 97, 29-38. [CrossRef]

39. Abnisa, F.; Daud, W.M.A.W.; Sahu, J.N. Pyrolysis of mixtures of palm shell and polystyrene: An optional method to produce a high-grade of pyrolysis oil. Environ. Prog. Sustain. Energy 2014, 33, 1026-1033. [CrossRef]

40. Lopez, G.; Alvarez, J.; Amutio, M.; Mkhize, N.M.; Danon, B.; Gryp, P.; Görgens, J.F.; Bilbao, J.; Olazar, M. Waste truck-tyre processing by flash pyrolysis in a conical spouted bed reactor. Energy Convers. Manag. 2017, 142, 523-532. [CrossRef]

41. Beccagutti, B.; Cafiero, L.; Pietrantonio, M.; Pucciarmati, S.; Tuffi, R.; Vecchio, S. Characterization of Some Real Mixed Plastics from WEEE: A Focus on Chlorine and Bromine Determination by Different Analytical Methods. Sustainability 2016, 8, 1107. [CrossRef]

42. Wongkhorsub, C.; Chindaprasert, N. A comparison of the use of pyrolysis oils in diesel engine. Energy Power Eng. 2013, 5, 350-355. [CrossRef]

43. Rohit, K.S.; Biswajit, R.; Sadhukhan, A.K.; Gupta, P. Impact of fast and slow pyrolysis on the degradation of mixed plastic waste: Product yield analysis and their characterization. J. Energy Inst. 2019, 92, 1647-1657.

44. Kasar, P.; Sharma, D.K.; Ahmaruzzaman, M. Thermal and catalytic decomposition of waste plastics and its co-processing with petroleum residue through pyrolysis process. J. Clean. Prod. 2020, 265, 121639. [CrossRef]

45. Williams, P.T. Pyrolysis of waste tyres: A review. Waste Manag. 2013, 33, 1714-1728. [CrossRef]

46. Williams, P.T.; Bottrill, R.P.; Cunliffe, A.M. Combustion of tyre pyrolysis oil. Trans. Inst. Chem. Eng. 1998, 76, 291-301. [CrossRef] 
47. Li, S.Q.; Yao, Q.; Chi, Y.; Yan, J.H.; Cen, K.F. Pilot-scale pyrolysis of scrap tires in a continuous rotary kiln reactor. Ind. Eng. Chem. Res. 2004, 43, 5133-5145. [CrossRef]

48. Usman, A.R.; Mahtab, A.; Mahrouky, M.; Omran, A.A.; Ok, Y.S.; Sallam, A.S.; El-Naggar, A.H.; Al-Wabel, M. Chemically modified biochar produced from conocarpus waste increases NO3 removal from aqueous solutions. Environ. Geochem. Health 2016, 38, 511-521. [CrossRef]

49. Sirotiak, M.; Bartošová, A.; Václavík, J. Possibilities of biomass modification to be sorbent of industrial contaminants. Nástroje Environ. Polit. 2019, 9, 21-30.

50. Akansu, S.O.; Tangöz, S.; Kahraman, N.; İlhak, M.İ.; Açıkgöz, S. Experimental study of gasoline-ethanol-hydrogen blends combustion in an SI engine. Int. J. Hydrogen Energy 2017, 42, 25781-25790. [CrossRef]

51. Reshad, A.S.; Tiwari, P.; Goud, V.V. Thermal and co-pyrolysis of rubber seed cake with waste polystyrene for bio-oil production. J. Anal. Appl. Pyrolysis 2019, 139, 333-343. [CrossRef]

52. Patsch, M.; Pilát, P. Non-limited emissions during glycerine combustion. EPJ Web Conf. 2012, $25,01068$. [CrossRef]

53. Vitázek, I.; Klúčik, J.; Jablonický, J.; Vereš, P. Ideal cycle of combustion engine with natural gas as a fuel. Res. Agric. Eng. 2016, 62, 14-20. [CrossRef]

54. Mishra, P.C.; Gupta, A.; Kumar, A.; Bose, A. Methanol and petrol blended alternate fuel for future sustainable engine: A performance and emission analysis. Measurement 2020, 155, 107519. [CrossRef]

(C) 2020 by the authors. Licensee MDPI, Basel, Switzerland. This article is an open access article distributed under the terms and conditions of the Creative Commons Attribution (CC BY) license (http://creativecommons.org/licenses/by/4.0/). 